NBER WORKING PAPER SERIES

THE WELFARE OF CHILDREN DURING THE GREAT DEPRESSION

Price V. Fishback

Michael R. Haines

Shawn Kantor

Working Paper 8902

http://www.nber.org/papers/w8902

\author{
NATIONAL BUREAU OF ECONOMIC RESEARCH \\ 1050 Massachusetts Avenue \\ Cambridge, MA 02138 \\ April 2002
}

Fishback is Frank and Clara Kramer Professor of Economics at the University of Arizona; Haines is Banfi Vintners Distinguished Professor of Economics at Colgate University; and Kantor is Professor of Economics at the University of Arizona. All three authors are Research Associates of the National Bureau of Economic Research. We thank Lee Alston, Howard Bodenhorn, William Horrace, Gary Libecap, Robert Margo, Richard Steckel, and John Wallis for helpful comments. Fishback and Kantor's work on this paper was supported by National Science Foundation Grant Numbers SBR-9708098 and SES- 0080324. Any opinions stated here are the authors' and not those of the NSF. The views expressed herein are those of the authors and not necessarily those of the National Bureau of Economic Research.

(C) 2002 by Price V. Fishback, Michael R. Haines and Shawn Kantor. All rights reserved. Short sections of text, not to exceed two paragraphs, may be quoted without explicit permission provided that full credit, including (C) notice, is given to the source. 
The Welfare of Children During the Great Depression

Price V. Fishback, Michael R. Haines and Shawn Kantor

NBER Working Paper No. 8902

April 2002

JEL No. I38, J11, N32

\begin{abstract}
This paper examines the impact of New Deal relief programs on demographic outcomes in major U.S. cities during the 1930s. A five-equation structural model is estimated that tests the effect of the relief spending on infant mortality, non-infant mortality, and fertility. For 111 cities for which data on relief spending during the 1930s were available, we collected annual data that matched the relief spending to the demographic variables, socioeconomic descriptions of the cities, and retail sales, which serve as a proxy for the level of economic activity. Relief spending directly lowered infant mortality rates to the degree that changes in relief spending can explain nearly one-third of the decline in infant mortality during the 1930s. Relief spending also raised general fertility rates. Our estimates suggest that the cost of saving an infant life during this period ranged from $\$ 2$ to 4.5 million dollars (measured in year 2000 dollars). This range is similar to that found in modern studies of the effect of Medicaid and is within the range of market values of human life.
\end{abstract}

Price V. Fishback

Department of Economics University of Arizona

Tucson, AZ 85721

and NBER

pfishback@bpa.arizona.edu
Michael R. Haines

Department of Economics

217 Persson Hall

Colgate University

13 Oak Drive

Hamilton, NY 13346

and NBER

mhaines@mail.colgate.edu
Shawn Kantor

Department of Economics

University of Arizona

Tucson, AZ 85721

and NBER

skantor@u.arizona.edu 


\section{The Welfare of Children During the Great Depression}

How well do social welfare programs mitigate the impact of economic downturns on society's most vulnerable, particularly children? While not addressing this question directly, a growing body of research has explored the impact of various modern social programs on the health and development of children. ${ }^{1}$ Focusing on relatively recent expansions in various programs' benefits or the cross-state differences in these benefits, the research has produced a mixed assessment of the effectiveness of modern public assistance. In this paper we reconsider this question by looking to a time when the U.S. suffered its most severe economic shock and when today's welfare programs were first introduced. Like some previous researchers, we use infant mortality as a benchmark for measuring children's well-being and examine how the relief programs of the New Deal alleviated the economic and social crisis of the Great Depression.

Unemployment rates rose sharply during the Depression to over 20 percent of the labor force and real GNP fell by roughly one-third between 1929 and 1933. Real GNP did not reach its 1929 level again until the end of the decade and the unemployment rate remained over 10 percent throughout the decade. Such a dramatic economic shock had significant effects on demographic outcomes. The sharp reductions in income put many more small children at risk of disease and death as the long-term rate of decline in the infant mortality rate slowed to a standstill during the early 1930s. Similarly, the shock of the Depression may have contributed to increases in death and morbidity among older children and adults as the long-term drop in the crude death rate essentially came to a halt. In addition, birth rates dropped faster than the pace set by earlier trends as families delayed births.

The economic shock also led to substantial changes in the forms and sources of social spending to provide relief to the poor and the unemployed. As the economy slid toward the trough of the Depression in the early 1930s, the burden of providing relief rested with state and local governments and private charitable organizations. Per capita relief spending rose from $\$ 3.90$ in 1930 to $\$ 18.70$ in 1932 (1967 dollars). The federal government played a limited role in the early part of the Depression by providing 
loans through the Reconstruction Finance Corporation so that state and local governments could fund relief in the latter part of 1932. It was Roosevelt's New Deal, however, that revolutionized welfare spending both in the short term and the long term. The federal government poured federal funds (sometimes in partnership with state and local governments) into the provision of emergency work relief and direct relief during the First New Deal (1933-1935). After 1935 the federal government continued with the provision of emergency work relief through the beginning of World War II. Under the Social Security Act, the Roosevelt Administration established a federal/state/local partnership in the provision of public assistance to dependent children, the blind, and the aged that replaced the much smaller state and local programs that had existed prior to the New Deal. Federal involvement in relief efforts led to dramatic increases in spending, as per capita relief expenditures increased by about 160 percent between 1932 and 1933 and by 1940 they were almost three times the 1932 level.

The cross-sectional variation in the Depression's economic shocks across the United States and in the government's response provide a unique opportunity to empirically examine the effectiveness of social welfare programs in times of crisis. Our analysis focuses on the New Deal relief programs' impact on key demographic variables: the infant mortality rate, the birth rate, and the non-infant crude death rate. ${ }^{2}$ Scholars have used measures of infant mortality as alternative assessments of well-being that supplement comparisons of per capita real GDP. Since children under the age of one probably have the least defenses against the problems of disease, malnutrition, and maltreatment, their death rates are probably affected most by negative economic shocks to the household. Infant mortality rates have been shown by numerous studies to be strongly associated with socioeconomic status, broadly defined. ${ }^{3}$ In fact, because the relief programs of the New Deal - and welfare programs more generally - were designed to help people in the lower tail of the income distribution, their impact on the infant mortality rate may well be one important measure of the programs' success.

To carry out the study we have developed a unique panel data set that enables us to measure the relationships between birth rates, infant mortality rates, non-infant death rates, and relief spending for 111 cities from 1930 to 1940. The U.S. Children's Bureau published annual information on public assistance 
for 1929 through 1935 (Winslow 1937) and the U.S. Social Security Board updated the series and carried the data forward through 1940 (Baird 1942). To this rich data set on relief spending, we then matched information on demographic outcomes in the cities, as well as socioeconomic variables (see the Data Appendix for details). Thus, the data that we have assembled not only captures the dramatic increase in relief spending that accompanied the New Deal's introduction in the early 1930s, but it also allows us to measure the effectiveness of the relief spending at a relatively low level of aggregation.

\section{Fertility and Mortality in the 1930s}

The national trends in both the non-infant death rate and the infant mortality rate show long-term declines prior to the 1930s (Cutler and Meara 2001). During the 1930s the infant mortality rate continued to decline, but at a much slower rate, while the non-infant death rate stopped falling and remained nearly constant. Although there had been a secular decline in the general fertility rate (number of births per thousand women aged 15 to 44) through the early twentieth century, there was a sharp drop during the Depression. In 1933 the national average fertility rate was nearly 10 births per thousand below what would have been predicted from the simple trend between 1915 and 1929. After 1933 the birth rate began to slowly rise and was well above the long-term trend by $1940 .{ }^{4}$

The average rates for the 111 cities in our sample show that the general trends experienced nationwide during the 1930 s were also experienced in the major U.S. cities. The general fertility rate, although lower than the overall national average of 89.2 in 1930, fell sharply between 1929 and 1933 before rising again during the recovery. The non-infant death rate held steady around 11 deaths per thousand live births throughout the 1930s. Meanwhile, the infant mortality rate experienced a significant decline in cities during the 1930 s despite a leveling-off period around 1933 to 1935 . Table 1 reports the average demographic experiences across the 111 cities in the sample.

The national averages for the cities disguise substantial variation across cities over the course of the decade. The average infant mortality rate for the 1930s ranged from a low of 30.1 infant deaths per 1,000 live births in Newton, Massachusetts to a high of 104.5 in El Paso, Texas. Similarly, the general 
fertility rate ranged from 44.5 in Chester, Pennsylvania to 107.4 in El Paso with a standard deviation of 9.9. The non-infant death rate displayed the smallest variation with a standard deviation of 1.83 . In general, the southern cities experienced higher rates of fertility, infant mortality, and non-infant death rates than the cities in other regions.

\section{Changes in Relief Spending by Federal, State, and Local Governments}

The relief programs in the 1930s included the provision of direct relief and work relief through a variety of programs. ${ }^{5}$ Direct relief included programs that had no specific work requirements. The relief was given in cash or in-kind and may have covered subsistence items, such as food, shelter, clothing and household necessities, or medical care and hospitalization. The amount was ordinarily adjusted to meet the needs of the specific relief case according to the budget-deficit principle. Work relief, as the name connotes, required a labor contribution in return for the benefit. The Federal Emergency Relief Administration (roughly 1933-1935) paid wages based on deficits between the household's income and an hypothesized budget for a family of that size. The Civil Works Administration (winter of 1933-1934) and the Works Progress Administration (roughly 1935-1940) provided jobs for the unemployed and lowincome persons, but paid fixed wages regardless of need. The wages, however, varied geographically. Table 1 shows the per capita annual relief expenditures in the 111 sample cities from 1930 to 1940.

Prior to 1933 the federal government played almost no role in providing relief spending beyond some aid to veterans (see Skocpol, 1992, ch. 2). As shown in Table 2, the federal government was the source of only 2.1 percent of the $\$ 207$ million in public aid expenditures in 1932 and the bulk of that was spending on workers' compensation for federal employees. State and local governments provided some limited forms of work relief and offered a series of state and local programs - mothers' pensions, old-age assistance, and aid to the blind - that were later replaced by similar programs established by the Social

Security Act. ${ }^{6}$ Roosevelt's New Deal led to an explosion in public aid expenditures, swamping the level of state and local spending, as the federal government's share of total expenditures rose to 79 percent in 1935. The federal government's first forays into relief spending came in the form of direct relief and work relief 
through the Federal Emergency Relief Administration (FERA) from 1933 to 1935 and the Civil Works Administration (CWA) in 1933 and the first part of 1934. During the Second New Deal (1935-39), the federal government continued to provide work relief through the Works Progress Administration (WPA) but returned much of the responsibility for direct relief of "unemployables" to state and local governments. The federal government did not completely get out of the direct relief process, as the Social Security Act of 1935 introduced the programs that served as the genesis of our modern social welfare system: old-age assistance, aid to dependent children, and aid to the blind. Beginning in 1936, federal grants-in-aid became available on a matching basis to states administering approved plans under the Social Security Act. By the end of 1938, all but 8 states were receiving federal grants. The shift in focus of the federal relief efforts and the eventual reductions in federal emergency work relief programs caused the federal share to slowly decline to 57 percent by 1940 .

Before starting into a full multivariate analysis of the data, we can get a sense of the impact of the rise in relief spending on the decline in infant mortality by performing a simple difference-in-difference experiment. The dramatic change in relief spending came with the introduction of large-scale federal relief after 1932. Therefore, for each city we calculated the average annual changes in per capita relief spending and the average annual changes in infant mortality rates between 1930-32 and 1933-40. Figure 1 shows a scatter plot of the differences in the relief spending and the differences in infant mortality rates over the two time periods. The differences in relief spending and the differences in infant mortality rates were negatively correlated with a value of -0.218 . A regression of the average change in infant mortality rates over the two periods on the change in per capita relief led to a statistically significant coefficient of -.096, which is similar to the effect we estimate in the structural model below. We have also divided the data into quartiles. Infant mortality rates for cities in the top quartile of relief spending fell by an average of -12.28 per thousand, compared with average falls of -10.1 in the third quartile, -9.2 in the second quartile, and 10.5 in the bottom quartile.

These simple calculations do not make full use of the annual variation in the data, nor do they take into account the dramatic changes in income and other factors that took place during this period. We 
therefore have developed a structural demographic model to control for these other factors, including the impact of changes in birth rates and death rates. We then use fixed effects for years and cities within the panel to perform a more extensive difference-in-difference analysis that captures the impact of relief spending on infant mortality and other demographic changes.

\section{An Empirical Model of the Demographic Effects of the New Deal}

Relief programs were designed to bolster the income of the unemployed and the non-working poor. We would anticipate that increased relief spending provided access to financial resources that would have enhanced the material well-being of families and their children. Increases in spending on such critical items as food, housing, or health care likely led to lower infant mortality and perhaps non-infant death rates. When discussing the impact of relief on infant mortality during the 1930 s, we focus on all forms of relief and do not confine our attention to the mothers' pension and ADC programs. In many states mothers' pensions were limited to widows with children, while the federal/state ADC program provided relief for children in households with at least one parent missing. These programs therefore focused on less than 7 percent of the households with infants under age one. ${ }^{7}$ The households with an absent parent were also eligible for aid through the FERA, CWA, and WPA because these programs determined eligibility by comparing the household's actual income to a target budget. Since aid under state mothers' pensions was not very generous, and a number of states were slow to adopt the legislation enabling the federal ADC program, it was likely that one-parent households received additional relief from these other New Deal programs. By focusing on total relief, as opposed to specific relief programs, we get a much better sense of the total relief available to all types of households with infant children.

Our expectations about the impact of greater relief spending on fertility rates are less clear. Studies suggest that such present-day welfare programs as Aid to Families with Dependent Children appear to have, at best, weak effects on birth rates (see, for example, Haveman and Wolfe 1994, ch.6; Blank 1995). Birth rates in the first few years of the Great Depression fell sharply below the trends from the 1920 s, as women and families delayed marriages and births. ${ }^{8}$ The new presence of the federal 
government as a provider of relief may have provided a broader safety net that encouraged families, at least in the lower end of the income distribution, to return to their pre-Depression fertility plans by the latter part of the 1930s.

Infant mortality rates, general fertility rates, and non-infant death rates all interact in ways that suggest the potential for a high degree of simultaneity. Therefore, we consider the effects of the New Deal on demographic outcomes in the context of a larger system of simultaneous equations:

$$
\begin{aligned}
& \mathrm{IMR}_{\mathrm{it}}=\mathrm{f}\left(\mathrm{GFR}_{\mathrm{it}}, \mathrm{NDR}_{\mathrm{it}}, \mathrm{R}_{\mathrm{it}}, \mathrm{Y}_{\mathrm{it}}, \mathrm{X}_{\mathrm{it}}, \mathrm{e}_{\mathrm{lit}}\right) \\
& \mathrm{GFR}_{\mathrm{it}}=\mathrm{g}\left(\mathrm{IMR}_{\mathrm{it}}, \mathrm{NDR}_{\mathrm{it}}, \mathrm{R}_{\mathrm{it}}, \mathrm{Y}_{\mathrm{it}}, Z_{\mathrm{it}}, \mathrm{e}_{2 \mathrm{it}}\right) \\
& \mathrm{NDR}_{\mathrm{it}}=\mathrm{h}\left(\mathrm{IMR}_{\mathrm{it}}, \mathrm{GFR}_{\mathrm{it}}, \mathrm{R}_{\mathrm{it}}, \mathrm{Y}_{\mathrm{it}}, \mathrm{M}_{\mathrm{it}}, \mathrm{e}_{3 \mathrm{it}}\right) . \\
& \mathrm{R}_{\mathrm{it}}=\mathrm{j}\left(\mathrm{IMR}_{\mathrm{it}}, \mathrm{GFR}_{\mathrm{it}}, \mathrm{NDR}_{\mathrm{it}}, \mathrm{Y}_{\mathrm{it}}, \mathrm{P}_{\mathrm{it}}, \mathrm{e}_{4 \mathrm{it}}\right), \\
& \mathrm{Y}_{\mathrm{it}}=\mathrm{k}\left(\mathrm{R}_{\mathrm{it}}, \mathrm{K}_{\mathrm{it}}, \mathrm{e}_{\mathrm{it}}\right)
\end{aligned}
$$

where $\mathrm{i}$ indexes the cities and $\mathrm{t}$ the years. The endogenous variables in the system of equations include the infant mortality rate (IMR, or the number of infant deaths per 1,000 live births), the general fertility rate (GFR, or the number of live births per 1,000 women aged 15-44), the non-infant death rate (NDR, or deaths above age one per 1,000 population), relief spending (R), and a measure of income or economic activity (Y). Because data on incomes during the 1930s do not exist for the cities, we use retail sales per capita as our proxy measure of economic activity. $\mathrm{X}_{\mathrm{it}}, \mathrm{Z}_{\mathrm{it}}, \mathrm{M}_{\mathrm{it}}, \mathrm{P}_{\mathrm{it}}$, and $\mathrm{K}_{\mathrm{it}}$ are sets of exogenous variables in the system. We assume all of the equations are linear.

Since our specific interest here is the demographic effects of relief spending, we focus our discussions on the first three equations of the system. Based on prior demographic research, we anticipate the following relationships between the infant mortality rate, the general fertility rate, and the non-infant death rate. The infant and non-infant mortality rates should be positively related to each other in the first and third equations to the extent that both infants and non-infants were struck by the same contagious diseases. We would expect a positive coefficient for the general fertility rate in the infant mortality equation. An increase in general fertility might contribute to higher infant mortality by shortening birth intervals with the consequence of less maternal care available per child and possibly shorter durations of 
breastfeeding. To the extent that families were seeking a target family size, higher death rates among infants might have led to increased fertility rates. This same link may exist between the non-infant mortality and fertility rates. There is evidence from other sources that about .6 to .8 of each child death was replaced in the United States around 1910. Only about .25 of this effect can be attributed to direct replacement, however, the rest seems to have been precautionary "hoarding" by parents trying to avoid the risk of having too few surviving children (Haines 1998, Table 7.6). ${ }^{9}$ Finally, in the non-infant death rate equation, we expect a positive sign on the general fertility rate because of increased probabilities of women dying in childbirth.

Each of the three demographic equations is identified because there are enough exogenous variables in the rest of the system that do not appear in each of the demographic equations. Consider, for example, the infant mortality equation. There are five endogenous variables in the equation; therefore, we need to have at least 4 exogenous variables in the $Z_{i t}, M_{i t}, P_{i t}$, and $K_{i t}$ vectors that are not included in the $X_{i t}$ vector. The $Z_{\text {it }}$ vector in the birth rate equation, for example, has a series of variables describing the age distribution of the female population in the prime birth years of 15 to 44 that do not belong in the other sets of exogenous variables in the system. ${ }^{10}$ The age distribution of women in their prime birth years should have influenced the birth rate among prime age women but not directly affected the infant mortality rate or the overall death rate. The infant mortality rate and the non-infant death rate might have been influenced by the age structure of the women who actually gave birth, but this is a different group from the percentage of prime fertility-age women who potentially could give birth, which is what we are measuring in the $Z_{\text {it }}$ vector.

In the death rate equation, $\mathrm{M}_{\mathrm{it}}$ contains a series of variables that describe the age distribution of the entire population - the percentages of persons aged 10-19, 20-29, 30-34, 35-44,45-54, 55-64, 65-74, over 74 , with the under 10 category left out. We would expect that death rates for the general population over age 1 would be influenced by the age distribution, with higher death rates associated with the oldest and the youngest segments of the population. However, these age groups would not be expected to affect the infant mortality rate because this measure focuses on children under one year old. Nor would the age 
distribution influence the general fertility rate because males are included in the overall population and their ages would have no affect on the potential fertility of the female population.

In the relief equations the $\mathrm{P}_{\text {it }}$ vector contains a set of political variables that describe the propensity of people in the county to vote for Democratic presidential candidates, the assignments of House of Representative members to ten key committees, the presence of a democratic governor in the state, the percentage of democrats in the upper house of the state legislature, and the percentage of democrats in the lower house of the state legislature. We would not expect these variables to have a direct impact on the demographic rates nor on retail sales per capita, however, there is evidence from the literature on the distribution of New Deal funds that they do affect the amount of relief spending (for example, see Wallis 1998).

The simultaneous equations in the system meet both the order and rank conditions for estimating two-stage least squares. In the IMR equation, the political variables in the $\mathrm{P}_{\mathrm{it}}$ vector, the variables for the age structure of the whole population in the $\mathrm{M}_{\mathrm{it}}$ vector, and the age structure variables for fertile women in the $Z_{\text {it }}$ vector all serve to identify the right-hand-side endogenous variables. Similarly, the age structure variables for the entire population in $\mathrm{M}_{\mathrm{it}}$ and the political variables in $\mathrm{P}_{\mathrm{it}}$ can serve as identifying variables for the endogenous variables on the right-hand side of the general fertility equation. The variables for the age distribution of fertile women in $Z_{i t}$ and the political variables in $\mathrm{P}_{\mathrm{it}}$ can serve as identifying instruments for the endogenous variables on the right-hand side of the non-infant mortality equation. We do not focus on the relief or retail sales equations, but the endogenous demographic variables in the relief equations are identified by the variables for the age structure of the whole population in the $\mathrm{M}_{\mathrm{it}}$ vector and the fertile women's age structure variables in the $Z_{\text {it }}$ vector. Similarly, in the retail sales equation, the right-hand side endogenous variables in those equations are identified by the political variables in $\mathrm{P}_{\mathrm{it}}$, the variables describing the age structure of the whole population in $\mathrm{M}_{\mathrm{it}}$, and the variables describing the age structure of fertile women in $Z_{i t}$. The instruments also include a number of exogenous variables that would be expected to appear in multiple equations, including the percent urban, percent rural non-farm, percent illiterate, percent black, and percent foreign-born. ${ }^{11}$ 
We also control for unmeasured heterogeneity across cities and across years. To control for the unchanging factors common to a particular city or year, we include city and year fixed effects. The city effects control for such factors as state and local spending on sanitation and public health measures that did not change much within a city over time, local customs, attitudes, diets, availability of medical care, cost of living, or climate. The year effects control for factors common to all cities within each year, such as shocks to the national economy that were spread uniformly across the country.

\section{Empirical Results}

The results of estimating the infant mortality, general fertility, and non-infant death rates using two stage least squares (2SLS) with and without fixed effects and using ordinary least squares with and without fixed effects are reported in Tables 3 through $5 .{ }^{12}$ The reported standard errors are based on White's (1980) correction for heteroskedasticity.

The results in the tables suggest that there are strong structural relationships between infant mortality, non-infant mortality, and birth rates. For the moment we will focus on the coefficients from the 2SLS estimations with fixed effects. All but one of the coefficients of the demographic rates in the structural equations are statistically significant at the 10 percent level. In the infant mortality equation we find that increases in the general fertility rate were associated with higher infant mortality. A one per thousand increase in the general fertility rate was associated with a 0.36 per thousand increase in the infant mortality rate. Moreover, infant mortality was very sensitive to changes in non-infant mortality, perhaps because of contagious diseases or common environmental hazards. A one per thousand increase in the non-infant crude death rate was associated with a 4.45 per thousand increase in the infant mortality rate.

From the results of the general fertility equation we detect signs that parents replaced children who died in their early years. A one per thousand increase in the infant mortality rate was associated with a 0.42 per thousand increase in the general fertility rate. A fraction of the non-infant deaths were children above the age of one, so we would also expect to see a positive relationship between the non-infant death rate and the general fertility rate. A one per thousand increase in the non-infant death rate led to a 1.57 per 
thousand increase in the general fertility rate, although this effect is not precisely estimated.

In the non-infant death rate equation, increases in the general fertility rate, which possibly led to greater risk of childbirth complications, were associated with higher death rates. There was a positive relationship between infant death rate and the non-infant death rate, which was also detected in the infant mortality equation. However, infant deaths appear to have been much more sensitive to non-infant deaths than the other way around.

\section{IV.1 The Direct Effect of Relief on Infant Mortality}

The relief programs were successful in alleviating the economic and resulting physical hardship that young children bore as a result of the Great Depression. In each regression specification, greater relief spending was associated with lower infant mortality during the 1930s and each coefficient is statistically significant. The various econometric specifications suggest different magnitudes of the effects. The inclusion of fixed effects to control for unmeasured heterogeneity across time and cities leads to smaller estimates of the relationship. On the other hand, the use of two-stage least squares to control for the endogeneity in the equations leads to higher estimates of the relationship. We believe the 2SLS estimates with fixed effects offers the most accurate coefficient because the estimation controls for both unmeasured heterogeneity and for endogeneity. The 2SLS with fixed effects estimate suggests that an additional per capita dollar of relief spending would have lowered the number of infant deaths (per 1,000 live births) by 0.128. ${ }^{13}$ One way to put the estimates into context is to consider the amount of relief spending that would have been required to save an infant's life. The top row of Table 6 contains estimates of the cost (in year 2000 dollars) to save one infant life, if we assume that the birth rate and non-infant death rate were not themselves affected by the relief spending. That is, suppose the number of infant deaths (I) can be written as

$$
\mathrm{I}(\mathrm{r})=\mathrm{IMR}(\mathrm{r}) * \mathrm{GFR} * \mathrm{~W} 1544 * \mathrm{P}
$$

where IMR is the infant mortality rate, GFR is the general fertility rate (births per women aged 15 to 44), $\mathrm{W} 1544$ is the share of the total population composed of women aged 15 to $44, \mathrm{P}$ is the total population, 
and $r$ is per capita relief spending. Differentiating with respect to $r$,

$$
\mathrm{dI} / \mathrm{dr}=\mathrm{dIMR}(\mathrm{r}) / \mathrm{dr} * \mathrm{GFR} * \mathrm{~W} 1544 * \mathrm{P}
$$

gives a measure of the direct effect of added relief spending on infant deaths. ${ }^{14}$ Using the 2SLS with fixed effects coefficient for $\mathrm{dIMR} / \mathrm{dr}$ of -0.128 and sample means for the other variables in equation (2), we estimate that saving an additional infant life would have cost approximately $\$ 2.5$ million (year 2000 dollars) in relief expenditures. ${ }^{15}$ When we consider the coefficients from the other specifications, the relief cost per life saved ranges from a low of $\$ 1.05$ million under the 2SLS without fixed effects model to a high of $\$ 7.7$ million under OLS with fixed effects. All of these estimates are roughly comparable to modern estimates of the market valuations of life, which range from about $\$ 1$ million to $\$ 9.5$ million. ${ }^{16}$ Some care must be exercised in making comparisons to market values of life because these estimates have been calculated for working adults. Thus, it is useful to compare the costs to other social welfare programs that more directly targeted children.

Currie and Gruber (1996b) estimated that targeted changes in the modern Medicaid system that lowered the eligibility requirements for specific groups spent $\$ 840,000$ to save an infant life. Of course, this estimate focused on specific changes in Medicaid that would have had a direct impact on children's health. When Currie and Gruber examined the impact of broader changes in the Medicaid program not specifically targeted at high-risk groups, the cost per life saved was about $\$ 4.2$ million. These comparisons suggest that during the economic crisis of the Great Depression, the flood of relief spending was roughly as cost effective in saving infant lives as modern Medicaid spending. It is important to remember that the purpose of relief spending during the Great Depression was not simply to prevent infant deaths; that was one of a number of welcome effects associated with alleviating economic hardship among the unemployed. With this caveat in mind and in comparison to the modern Medicaid program, it appears that relief spending during the 1930 s was relatively effective in enhancing the material well-being of infants.

Another way to put the impact of relief spending on infant mortality into perspective is to examine how much of the change in infant mortality during the 1930s might be attributable to the dramatic increases in relief spending. Over the course of the 1930 s, the population-weighted average infant 
mortality rate in the city sample fell by 20.4 per thousand, from 59.8 in 1930 to 39.4 in 1940 . During the same period per capita relief spending rose by approximately $\$ 48$, from $\$ 3.9$ in 1930 to $\$ 52.7$ in 1940 (in constant 1967 dollars). Based on the 2SLS with fixed effects coefficient of -0.128 , this increase in relief spending was associated with a reduction of 6.25 infant deaths per thousand live births. Given that the decline in average infant mortality rates in the sample over the decade was 20.3 infant deaths per thousand live births, the rise in relief spending can account for roughly 31 percent of the decline in infant mortality in the 1930s. If we use the coefficients from the other specifications, the share of the decline attributable to greater relief spending ranges from a low of 10 percent to a high of 72 percent. Our sense is that the relief programs had such a dramatic effect on infant mortality because the Depression pushed an unusually large percentage of families to the precipice of financial survival. A relatively small amount of financial assistance during a severe economic crisis apparently can have a profound effect on children's survival.

\section{IV.2 The Direct Effect of Relief on Birth Rates}

Given the significant modern debate over the impact of welfare spending on fertility decisions, it is worth focusing on the results from the New Deal when welfare expanded dramatically. The Great Depression led to sharp reductions in income and, as a result, contributed to a reduction in fertility rates. The average general fertility rate in our sample of cities fell from 69.4 in 1930 to 56.7 in 1933 as real GDP fell drastically. Postponement of both marriages and births took place. ${ }^{17}$ As the economy began to recover, the general fertility rate returned to around 62 by 1940 . The 2SLS with fixed effects analysis shows the importance of economic activity to the fertility decision, as a one hundred dollar increase in per capita retail sales would have led to an increase of 0.448 births per 1,000 women aged 15 to 44 . The coefficients using the other specifications were also positive but smaller.

The coefficients of the relief spending variable are sensitive to specification. The 2SLS with fixed effects coefficient in Table 4 suggests that a one dollar increase in per capita relief increased the general fertility rate by a statistically significant 0.083 births per thousand women of prime fertility age. The coefficient is much smaller in the OLS with fixed effects model, but positive and statistically insignificant. 
In the 2SLS and OLS models without fixed effects, the coefficients are negative and statistically significant. Thus, it is not at all clear that the rapid expansion of welfare during the New Deal caused women families to alter their fertility plans, as has been suggested for the modern era.

\section{IV.3 The Indirect Impact of Relief Spending on Infant Mortality}

When we calculated the amount of relief spending necessary to save an infant's life above, we only focused on the direct effect of relief spending on infant mortality. However, there were also indirect channels through the fertility rate and the non-infant death rate that relief spending may have affected infant mortality. Estimation of the structural equations shows that the infant mortality rate increased with increases in the general fertility rate and in the non-infant death rate. Thus, if relief spending reduced the non-infant death rate, then infant mortality rate would have fallen further, thus lowering our cost estimate of saving an infant's life. On the other hand, if more relief spending contributed to higher fertility rates, then there would have been greater infant mortality and the cost of saving a life would have been higher.

To show these indirect effects, we can rewrite equation (1) above to reflect the fact that the infant mortality rate and the general fertility rate are functions not only of relief spending, $r$, but also the other demographic rates:

$$
\mathrm{I}(\mathrm{r})=\mathrm{IMR}(\mathrm{r}, \mathrm{GFR}(\mathrm{r}), \mathrm{NDR}(\mathrm{r})) * \mathrm{GFR}(\mathrm{r}, \mathrm{IMR}(\mathrm{r}), \mathrm{NDR}(\mathrm{r})) * \mathrm{~W} 1544 * \mathrm{P},
$$

where NDR is the non-infant death rate. Differentiating with respect to relief spending in this case leads to the following expression

$$
\begin{aligned}
\partial \mathrm{I} / \partial \mathrm{r}= & (\partial \mathrm{IMR} / \partial \mathrm{r}+\partial \mathrm{IMR} / \partial \mathrm{GFR} * \partial \mathrm{GFR} / \partial \mathrm{r}+\partial \mathrm{IMR} / \partial \mathrm{NDR} * \partial \mathrm{NDR} / \partial \mathrm{r}) * \mathrm{GFR}(\bullet) * \mathrm{~W} 1544 * \mathrm{P}+ \\
& (\partial \mathrm{GFR} / \partial \mathrm{r}+\partial \mathrm{GFR} / \partial \mathrm{IMR} * \partial \mathrm{IMR} / \partial \mathrm{r}+\partial \mathrm{GFR} / \partial \mathrm{NDR} * \partial \mathrm{NDR} / \partial \mathrm{r}) * \mathrm{IMR}(\bullet) * \mathrm{~W} 1544 * \mathrm{P}
\end{aligned}
$$

The equation shows how the indirect influences of the various demographic rates on the others and relief spending on the birth rate and non-infant death rate work through the system. ${ }^{18}$

Our estimates in Table 5 suggest that relief spending did virtually nothing to reduce the non-infant death rate during the 1930s. In fact, it appears that increases in income more generally, as proxied by retail sales, also did little to lower the death rate. There was a negative, statistically significant coefficient in an 
OLS estimation, but this did not control for unexplained heterogeneity or for the endogeneity in the system. Thus, to simplify the calculation, we have set $\partial \mathrm{NDR} / \partial \mathrm{r}$ equal to zero and equation (5) simplifies to:

$$
\begin{aligned}
\partial \mathrm{I} / \partial \mathrm{r}= & (\partial \mathrm{IMR} / \partial \mathrm{r}+\partial \mathrm{IMR} / \partial \mathrm{GFR} * \partial \mathrm{GFR} / \partial \mathrm{r}) * \mathrm{GFR}(\bullet) * \mathrm{~W} 1544 * \mathrm{P}+(\partial \mathrm{GFR} / \partial \mathrm{r}+\partial \mathrm{GFR} / \partial \mathrm{IMR} \\
& * \partial \mathrm{IMR} / \partial \mathrm{r}) * \mathrm{IMR}(\bullet) * \mathrm{~W} 1544 * \mathrm{P} .
\end{aligned}
$$

Using this more complicated expression to account for the secondary effects of relief spending, we can determine the number of infant deaths saved as a result of an additional dollar of relief spending per capita. The results of this calculation, assuming samples means for P, W1544, GFR, and IMR, are shown in the second row of Table 6. Using the coefficients from the 2SLS fixed effects model, saving an infant's life would have cost roughly $\$ 4.2$ million (year 200 dollars) in relief spending. Taking into account the secondary effects leads to an estimate that is 70 percent higher than the one that only considered a direct link between relief spending and infant mortality. The new cost measure is higher because increased relief spending would have increased the birth rate and, in turn, the infant mortality rate. However, the estimate is still within the range of modern market values of life and roughly comparable to Currie and Gruber's (1996b) estimates of the cost per infant life saved from general changes in the Medicaid program. The other empirical specifications led to cost estimates ranging from a low of $\$ 701,000$ using the 2SLS without fixed effects model to a high of \$11 million using the OLS with fixed effects coefficients.

\section{Concluding Remarks}

The 1930 s provide a unique opportunity to test the impact of social welfare spending on children because the economic crisis was so severe and the government's response was equally unprecedented. The Great Contraction from 1929 to 1933 led to sharp reductions in birth rates, which fell well below the longterm trend. Meanwhile, the long-term declines in mortality rates were slowed during the 1930 s. Prior to the New Deal state and local governments bore the primary responsibility of providing relief to the poor, but their ability to meet the overwhelming needs of their citizens during the early years of the Depression was quickly swamped. Even though state and local governments increased their relief spending two to 
three-fold in the early 1930s, their levels of spending were limited by their diminishing tax bases and their ability to issue debt. The federalization of the relief effort in the form of emergency New Deal programs dramatically increased the levels of welfare spending.

Direct financial assistance and work relief were the leading forms of public aid to the poor during the 1930s. The results of our analysis indicate that these welfare programs played an important role in mitigating the deleterious effects of the Great Depression, especially for highly vulnerable segments of the population such as children. Roughly one-third of the decline in infant mortality rates over the course of the 1930 s might be attributable to the increases in relief spending. The results of the paper, with its focus on an extraordinary time in U.S. economic and social welfare history, add to the growing body of evidence that the material well-being of very young children can be enhanced as a result of public aid to their financially stressed families. 


\section{Data Appendix}

The sample consists of annual observations for 111 cities between 1930 and 1940 . The sample constituted the specific 111 cities because information on relief spending each year from 1929 through 1940 were available in a unique source. ${ }^{19}$ The data collection project was initiated in 1929 at the Russell Sage Foundation and was later transferred to the U.S. Children's Bureau, which collected the relief information and published a volume covering the period 1929 through 1935 (Winslow 1937). The project was transferred again to the Social Security Board, which updated the series and carried the data forward through 1940 (Baird 1942). The aggregate population of the sample cities accounted for 37 percent of the total U.S. population and 66 percent of the total urban population.

The city-level relief information was then matched to data on infant and non-infant mortality and birth rates from U.S. Bureau of the Census (1934a, b, c; 1936a, b; 1937; 1938; 1939; 1940; 1941; 1942). The relief spending for a number of the urban areas was reported for the entire county in which the city was located, but just for the city in other cases. Since we had both city and county information on mortality and births rates for all of these areas, we were able to match city infant mortality rates for the cities that reported relief spending only for the city and county information for urban areas that reported relief spending for the county.

We sought an effective method of controlling for the substantial changes in income that occurred during the time period. In the absence of estimates of per capita income at the city level, we chose retail sales per capita as a proxy. Retail sales are strongly correlated with consumption and with income, particularly in urban areas, and we had sales information for the counties in which the cities were located for 1929, 1933, 1935, and 1939. Retail sales from 1929 and 1939 come from ICPSR file number 0003, as amended and corrected by Michael Haines. Retail sales in 1933 and 1935 are from U.S. Department of Commerce, Bureau of Foreign and Domestic Commerce $(1936,1939)$. The population estimate used to create the per capita measure was based on straight-line interpolations between 1920,1930, and 1940 data from the amended ICPSR file 0003 . We interpolated values of per capita retail sales in the intervening years using estimates of state personal income from the U.S. Bureau of Economic Analysis (1989). For 
each year between 1930 and 1940, we divided state personal income by an estimate of state population. Then to interpolate per capita retail sales between the benchmark years of 1929, 1933, 1935, and 1939, we used a formula like the one below for 1931:

$$
\mathrm{R}_{31}=\mathrm{R}_{29}+\left(\mathrm{R}_{33}-\mathrm{R}_{29}\right) *\left(\mathrm{~S}_{31}-\mathrm{S} 29\right) /\left(\mathrm{S}_{33}-\mathrm{S}_{29}\right)
$$

where $\mathrm{R}$ is per capita retail sales in the appropriate year for the county in which the city was located and $\mathrm{S}$ is per capita state personal income in the same year.

We sought to control for other demographic characteristics of the cities, such as ethnicity, nativity, illiteracy, and the extent of urbanization. Given the nature of the available data, these variables are measured at the county level. The exception is that if the relief data was reported for a specific city, and not just the county containing the city, we set the percent urban equal to 100 . The information for 1930 and 1940 is from the amended ICPSR file number 0003 . The measures of the age distribution at the county level are from Gardner and Cohen (1992). We used straight-line interpolations to populate the variables between 1930 and 1940.

We discovered that these independent variables did not vary dramatically over time, so as an alternative we controlled for the differences in demographic variables across cities, and other types of heterogeneity across urban areas that were unchanged over time, by including fixed effects for the urban areas. We also controlled for factors that were common to all of the urban areas in each year, but that changed over time, by included year effects in the regressions as well.

We used a variety of instruments in the relief equations relating to the political atmosphere in the cities or their states. The percent voting for democratic presidential candidates in the county where the city was located is calculated from ICPSR file number 0001. The value of the variable between election years was the value from the preceding election. The variables measuring representation on House committees between 1933 and 1938 are from U.S. Congress (various years). The democratic governor variable is from Congressional Quarterly Inc. (1995, 639-63). The information on the percent democrat in each state legislature comes from legislative manuals, state bluebooks, and House and Senate journals for each state from the collection housed at the Wisconsin State Historical Society. In many of the southern states the 
legislatures were overwhelmingly Democratic and many of the bluebooks did not bother to list party affiliations. To fill in any gaps we encountered, we used information from the New York Secretary of State, Manual, for the years 1925-1940. 


\section{FOOTNOTES}

${ }^{1}$ For recent studies that have examined how modern social programs affect the status of children, see Grossman and Jacobowitz (1981), Currie and Cole (1993), Haveman and Wolfe (1994), Currie and Thomas (1995a and 1995b), Currie and Gruber (1996a, 1996b, and 2001), Duncan and Brooks-Gunn (1997), Joyce (1999), and Blau (1999). Moreover, see Moffitt and Ver Ploeg (2001) for an extensive discussion of the current research underway examining the economic and social consequences of the 1996 Personal Responsibility and Work Opportunity Reconciliation Act that overhauled the modern welfare system.

${ }^{2}$ The infant mortality rate is the number of deaths of children below age 1 per 1,000 live births. The noninfant crude death rate is the number of deaths of people above age 1 per 1,000 population. The general fertility rate is total live births per 1,000 women aged 15 to 44 .

${ }^{3}$ See Antonovsky and Bernstein (1977), Clifford and Brannon (1978), Waldman (1992), and Haines (2000). For a more general discussion of how socioeconomic status of parents affects the treatment of children, see Paxson and Waldfogel (1999).

${ }^{4}$ See Fishback, Haines, and Kantor (2001) for discussions of the national trends and for an examination of the impact of a wide variety of New Deal programs on the various demographic rates for both whites and blacks in southern counties. Studying demographic trends at the county level has some disadvantages relative to the current study because county-level information on relief spending by state and local governments and private agencies across the United States is not available. The relief spending we focus on here includes spending by all levels of government.

${ }^{5}$ Our relief measure includes some privately administered relief spending, which accounted for roughly one-quarter of relief spending prior to 1933, but less than one percent thereafter. The monies for the privately administered relief in many cases came from government sources. More detailed breakdowns for urban areas can be found in Baird (1942). Several programs that might be considered public assistance were not included in the reported relief data. For example, FERA emergency education, student aid, and transient programs were omitted. There is no information on the Civilian Conservation Corp, which provided employment in more isolated areas for many youths who came from urban areas. Spending on the National Youth Administration was omitted, as was the distribution of federal surplus commodities, which were bought from farmers as an agricultural relief measure. This form of relief did not account for a large share of aid in urban areas, but was important in rural areas. Also, information on earnings under the Public Works Administration were not included. But these projects tended to hire more skilled workers and, thus, the program's exclusion probably does not affect our conclusions regarding the effect of relief on the relatively poor.

${ }^{6}$ Some state and local spending in the latter half of 1932 was financed by loans from the Reconstruction Finance Corporation. State old-age assistance laws provided for cash payments that would allow the elderly to live on their own. By 1932, 18 states were paying out pensions to 102,537 persons totaling $\$ 22.5$ million. While most states provided educational and vocational training services for the blind, by August 1935 there were 27 states providing direct cash payments to the blind. U.S. Bureau of Labor Statistics (1935, 584-601) estimates showed that in 1934 approximately two-thirds of the blind population was receiving some form of cash grants (Stevens 1970, 29-31). "Aid to dependent children" prior to 1935 was commonly known as mothers' aid, mothers' pensions, or aid to widows. These early programs were established under state law and by 1935 every state except Georgia and South Carolina had laws providing for mothers' aid funds. For a description of the laws circa 1934, see Stevens (1970, 20-31) and U.S. Committee on Economic Security $(1937,156-170,233-49)$. For a description of the timing of the laws, see Thompson (1919), Skocpol (1992, 457), and Fishback and Thomasson (forthcoming).

${ }^{7}$ We based this calculation on households reported in the IPUMS from 1940.

${ }^{8}$ We estimated a linear time trend for the general rate over the period 1915 to 1929 from the national data. We then predicted the trend for the 1930s and subtracted the trend birth rate from the actual general fertility rate. The negative deviation from trend was -3.38 in 1930 and increased (in absolute value) to -9.43 in 1933. After several more years below trend the actual birth rate hit the trend birth rate in 1937 
and then proceeded to rise above it by 4.78 in 1938, 5.57 in 1939, and over 10 in 1940 .

${ }^{9}$ There might be some replacement effect associated with the non-infant death rate, but most childhood deaths occurred in infancy. The proportion of all deaths below age 5 that occurred between the ages of 1 and 4 was 24.4 percent in 1932 and 17.8 percent in 1940. The proportion of deaths for children aged 1 to 4 relative to all non-infant deaths was 3.9 percent in 1930 and 1.8 percent in 1940.

${ }^{10}$ Specifically, the instrumental variables are the percentages of women aged 15 to 44 who are 15 to 19 , 20-24, 25-29, and 30-34. The 35-44 category is left out.

${ }^{11}$ We know it appears odd to include percent urban and percent rural non-farm measures in a panel of city observations. The relief data were reported at the county level for a number of the city areas and thus we matched up the demographic data in those areas based on the counties. In some of these counties there were farm and rural non-farm populations.

${ }^{12}$ The birth and death rates can be considered probabilities bounded below by zero. There might be a worry about estimating models where the dependent variables are linear probabilities because the coefficient estimates might lead to predictions from the model that are negative. However, all of the predictions from our models are greater than zero; therefore, we did not explore alternative specifications. See Horrace and Oaxaca (2001) for discussions of methods for estimating models with linear probabilities. ${ }^{13}$ The results for infant mortality reported in Table 5 are similar to those we obtained when we estimated a reduced-form infant mortality equation that included relief spending, but omitted the general fertility rate, the non-infant death rate, or per capita retail sales from the equation. The relief coefficient is -.108 when we estimate 2SLS with fixed effects, -.257 under 2SLS without fixed effects, -.038 under OLS with fixed effects, and -.257 under OLS without fixed effects. All were statistically significant at the 5 percent level in two-tailed t-tests.

We also experimented with a model in which we estimated the difference between infant mortality and non-infant mortality as the dependent variable as a way to control for unmeasured differences in factors such as sanitation that might have changed over time. In essence the current version of the structural model does something like this because the relief coefficient shows the impact on the infant mortality rate holding constant the non-infant death rate. Nonetheless, we estimated reduced-form versions of the model with the difference between infant mortality and non-infant mortality as the dependent variable and the results suggest that relief spending lowered infant mortality more than it lowered noninfant mortality.

${ }^{14}$ There might be indirect effects from relief spending as well. For example, relief spending may have affected birth rates or the non-infant death rates, which, in turn, may have affected infant deaths. We take up this issue in section IV.3 below.

${ }^{15}$ Another way to describe the calculation is as follows. The 2SLS estimate with fixed effects suggests that an additional per capita dollar (1967 dollars) spent on direct relief would have lowered infant mortality by 0.128 per thousand live births. Based on the sample means of our data, in the average city of 500,000 people, there would have been 8,217 live births during the 1930s. Holding the number of live births constant, an additional dollar of relief per capita in 1967 dollars would have cost an extra $\$ 500,000$ citywide and this spending would have saved 1.052 infants from death $(0.128 * 8,217)$. Dividing the $\$ 500,000$ in relief spending into the number of infants saved suggests that it cost $\$ 475,358$ in relief funds per infant death averted. Adjusting this 1967 value to 2000 dollars using the CPI (Council of Economic Advisors $2001,346)$, the relief cost would have been $\$ 2,476,414$ in year 2000 dollars.

${ }^{16}$ Market values of life are from Moore and Viscusi $(1990,14)$ with adjustments to year 2000 values using the GDP Deflator (Council of Economic Advisors 2001, 282).

${ }^{17}$ For example, the number of marriages declined from $1,233,000$ in 1929 to 982,000 in 1932 . The number of live births declined from 2,618,000 in 1930 to 2,307,000 in 1933 (U.S. Bureau of the Census, 1975, Series B 1-4).

${ }^{18}$ Since each demographic rate on the right hand side could be written as a function of the other demographic rates, we could differentiate an infinite loop of expressions. We express the second-order demographic functions on the right hand side of the expression simply as functions of relief spending, $r$, to 
avoid worrying about relatively small third-order effects.

${ }^{19}$ The sources for the relief spending actually included 116 cities, but because data could not be collected for critical variables in our estimations we lost four cities: Washington, DC; Duluth, MN; Minneapolis, MN; St. Paul. MN. Further, Allentown, PA and Bethlehem, PA, which were reported separately in the relief data, were combined into one city-observation because of other data constraints. 
Table 1

Trends in Vital Statistics and Relief Spending for 111 U.S. Cities, 1930 to 1940

\begin{tabular}{rrrrr}
\hline Year & $\begin{array}{c}\text { General } \\
\text { Fertility } \\
\text { Rate }\end{array}$ & $\begin{array}{c}\text { Non-Infant } \\
\text { Death Rate }\end{array}$ & $\begin{array}{c}\text { Infant } \\
\text { Mortality } \\
\text { Rate }\end{array}$ & $\begin{array}{c}\text { Per capita } \\
\text { relief } \\
\text { spending } \\
\mathbf{( 1 9 6 7 ~ \$ ) ~}\end{array}$ \\
\hline $\mathbf{1 9 3 0}$ & 69.4 & 11.4 & 59.8 & 3.86 \\
$\mathbf{1 9 3 1}$ & 64.4 & 11.4 & 58.7 & 9.32 \\
$\mathbf{1 9 3 2}$ & 61.1 & 11.1 & 53.2 & 18.55 \\
$\mathbf{1 9 3 3}$ & 56.7 & 11.0 & 52.3 & 29.76 \\
$\mathbf{1 9 3 4}$ & 57.4 & 11.2 & 53.1 & 47.04 \\
$\mathbf{1 9 3 5}$ & 57.3 & 11.2 & 50.0 & 50.96 \\
$\mathbf{1 9 3 6}$ & 56.8 & 11.7 & 49.7 & 61.49 \\
$\mathbf{1 9 3 7}$ & 58.5 & 11.6 & 46.7 & 51.86 \\
$\mathbf{1 9 3 8}$ & 60.4 & 10.9 & 42.5 & 69.15 \\
$\mathbf{1 9 3 9}$ & 59.6 & 11.0 & 40.7 & 62.93 \\
$\mathbf{1 9 4 0}$ & 62.7 & 11.2 & 39.4 & 52.71 \\
\hline
\end{tabular}

Notes: The averages are weighted by the populations of the counties in which the cities are located. For 1930-1932 the averages do not include information for the Texas cities in the sample because such data were not available. The infant mortality rate is the number of deaths of children under age one per thousand live births in each year. The general fertility rate is the number of births in each year per thousand women aged 15 to 44 . The number of women aged 15 to 44 for the years 1931 through 1939 were determined by straight-line interpolations between the decennial censuses. The non-infant death rate is the number of deaths of persons aged 1 year and older each year per 1000 people. The populations for 1931 through 1939 were determined by straight-line interpolations between 1930 and 1940. Direct relief includes direct relief under the FERA, by state and local governments, and categorical assistance for dependent children (mothers' pensions prior to 1935), old-age assistance, and aid to the blind. Work relief includes payments to workers on state and local government, FERA, CWA, and WPA projects. Private relief is the value of relief funds from private and public sources administered by private agencies.

Sources: See Data Appendix. 
Table 2

Relief Expenditures, by Level of Government, 1932-1940

\begin{tabular}{llrrrr}
\hline & & \multicolumn{2}{c}{ Federal share } & \multicolumn{2}{c}{ State and local share } \\
\cline { 3 - 6 } Fiscal year ending & \multirow{2}{*}{$\begin{array}{c}\text { Total } \\
\text { June 30, }\end{array}$} & $\begin{array}{c}\text { Amount } \\
\mathbf{( 0 0 0 )}\end{array}$ & $\begin{array}{c}\text { Percent of } \\
\text { (000) }\end{array}$ & \multicolumn{1}{c}{$\begin{array}{c}\text { Amount } \\
\mathbf{( 0 0 0 )}\end{array}$} & $\begin{array}{c}\text { Percent of } \\
\text { total }\end{array}$ \\
\hline $\mathbf{1 9 3 2}$ & $\$ 207,562$ & $\$ 4,411$ & 2.1 & $\$ 203,151$ & 97.9 \\
$\mathbf{1 9 3 3}$ & 739,481 & 383,115 & 51.8 & 356,366 & 48.2 \\
$\mathbf{1 9 3 4}$ & $2,544,753$ & $2,007,363$ & 78.9 & 537,390 & 21.1 \\
$\mathbf{1 9 3 5}$ & $3,018,287$ & $2,382,358$ & 78.9 & 635,929 & 21.1 \\
$\mathbf{1 9 3 6}$ & $3,092,019$ & $2,310,199$ & 74.7 & 781,820 & 25.3 \\
$\mathbf{1 9 3 7}$ & $3,516,432$ & $2,535,007$ & 72.1 & 981,425 & 27.9 \\
$\mathbf{1 9 3 8}$ & $3,635,551$ & $2,252,517$ & 62.0 & $1,383,034$ & 38.0 \\
$\mathbf{1 9 3 9}$ & $4,945,865$ & $3,091,120$ & 62.5 & $1,854,745$ & 37.5 \\
$\mathbf{1 9 4 0}$ & $4,455,145$ & $2,558,348$ & 57.4 & $1,896,797$ & 42.6 \\
\hline
\end{tabular}

Notes: The values include the cost of administering the programs. The 1932 federal figure includes $\$ 3.7$ million in workers' compensation payments. The state and local expenditures include workers' compensation, general relief, old-age assistance, aid to dependent children, aid to the blind, and state shares of unemployment compensation, WPA, CWA, and the National Youth Administration.

Source: U.S. National Resources Planning Board (1942, 292, 598-603). 
Table 3

Infant Mortality Rate Regressions

\begin{tabular}{|c|c|c|c|c|c|c|c|c|}
\hline & \multicolumn{4}{|c|}{ Two Stage Least Squares } & \multicolumn{4}{|c|}{ Ordinary Least Squares } \\
\hline & \multicolumn{2}{|c|}{ Fixed Effects } & \multicolumn{2}{|c|}{ No Fixed Effects } & \multicolumn{2}{|c|}{ Fixed Effects } & \multicolumn{2}{|c|}{ No Fixed Effects } \\
\hline & Coeff. & std. err. & Coeff. & std. err. & Coeff. & std. err. & Coeff. & std. err. \\
\hline Constant & -26.090 & 49.685 & 41.245 & 9.912 & -102.561 & 42.588 & 15.608 & 7.457 \\
\hline General fertility rate & 0.358 & 0.109 & 0.115 & 0.060 & -0.086 & 0.055 & 0.260 & 0.031 \\
\hline Non-infant death rate & 4.448 & 0.939 & 1.327 & 0.238 & 5.320 & 0.381 & 1.890 & 0.168 \\
\hline Relief spending, per capita & -0.128 & 0.041 & -0.301 & 0.023 & -0.041 & 0.017 & -0.204 & 0.013 \\
\hline Retail sales, per capita & -1.603 & 11.049 & -20.680 & 3.248 & -3.029 & 2.865 & -13.601 & 1.556 \\
\hline Percent black & -0.436 & 0.772 & -0.130 & 0.078 & -0.365 & 0.776 & 0.010 & 0.066 \\
\hline Percent illiterate & 0.119 & 0.785 & 2.643 & 0.341 & -0.998 & 0.753 & 2.115 & 0.280 \\
\hline Percent urban & 0.254 & 0.474 & 0.190 & 0.069 & 1.081 & 0.432 & 0.180 & 0.067 \\
\hline Percent rural, non-farm & 0.529 & 0.650 & 0.013 & 0.097 & 1.694 & 0.593 & 0.056 & 0.094 \\
\hline Percent foreign born & -0.653 & 0.496 & -0.675 & 0.090 & 0.160 & 0.455 & -0.536 & 0.079 \\
\hline City dummy variables & \multicolumn{2}{|c|}{ included } & \multicolumn{2}{|c|}{ not included } & \multicolumn{2}{|c|}{ included } & \multicolumn{2}{|c|}{ not included } \\
\hline Year dummy variables & \multicolumn{2}{|c|}{ included } & \multicolumn{2}{|c|}{ not included } & \multicolumn{2}{|c|}{ included } & \multicolumn{2}{|c|}{ not included } \\
\hline \# of observations & \multicolumn{2}{|c|}{1201} & \multicolumn{2}{|c|}{1201} & \multicolumn{2}{|c|}{1201} & \multicolumn{2}{|c|}{1201} \\
\hline R-squared & \multicolumn{2}{|c|}{0.871} & \multicolumn{2}{|c|}{0.603} & \multicolumn{2}{|c|}{0.881} & \multicolumn{2}{|c|}{0.647} \\
\hline
\end{tabular}

Sources: See Data Appendix. 
Table 4

General Fertility Rate Regressions

\begin{tabular}{|c|c|c|c|c|c|c|c|c|}
\hline & \multicolumn{4}{|c|}{ Two Stage Least Squares } & \multicolumn{4}{|c|}{ Ordinary Least Squares } \\
\hline & \multicolumn{2}{|c|}{ Fixed Effects } & \multicolumn{2}{|c|}{ No Fixed Effects } & \multicolumn{2}{|c|}{ Fixed Effects } & \multicolumn{2}{|c|}{ No Fixed Effects } \\
\hline & Coeff. & std. err. & Coeff. & std. err. & Coeff. & std. err. & Coeff. & std. err. \\
\hline Constant & -314.8 & 77.982 & -256.9 & 41.656 & -389.8 & 48.744 & -228.1 & 33.762 \\
\hline Infant mortality rate & 0.417 & 0.143 & 0.246 & 0.082 & -0.041 & 0.017 & 0.154 & 0.026 \\
\hline Non-infant death rate & 1.565 & 1.133 & 2.614 & 0.366 & 1.965 & 0.256 & 1.696 & 0.178 \\
\hline Relief spending, per capita & 0.083 & 0.037 & -0.106 & 0.029 & 0.016 & 0.009 & -0.070 & 0.011 \\
\hline Retail sales, per capita & 44.827 & 9.993 & 4.432 & 4.059 & 14.664 & 2.963 & 15.422 & 1.320 \\
\hline Percent black & -0.200 & 0.677 & -0.294 & 0.068 & 0.033 & 0.576 & -0.123 & 0.064 \\
\hline Percent illiterate & -0.548 & 0.688 & -0.808 & 0.354 & -0.668 & 0.494 & -0.420 & 0.293 \\
\hline Percent urban & 1.531 & 0.479 & -0.232 & 0.070 & 2.139 & 0.378 & -0.278 & 0.063 \\
\hline Percent rural, non-farm & 1.665 & 0.597 & -0.151 & 0.092 & 2.663 & 0.466 & -0.171 & 0.085 \\
\hline Percent foreign born & 1.034 & 0.317 & 0.391 & 0.083 & 0.792 & 0.232 & 0.272 & 0.059 \\
\hline \multicolumn{9}{|c|}{ Percent of women aged 15 to 44 within: } \\
\hline Ages 15-19 & 3.663 & 1.119 & 6.903 & 0.600 & 4.888 & 0.638 & 6.656 & 0.492 \\
\hline Ages $20-24$ & -2.596 & 1.030 & -0.768 & 0.766 & -0.969 & 0.836 & 0.494 & 0.698 \\
\hline Ages 25-29 & 4.060 & 1.163 & 6.227 & 0.988 & 3.044 & 0.848 & 3.878 & 0.858 \\
\hline Ages 30-34 & 2.229 & 1.423 & 4.936 & 1.419 & 4.352 & 1.035 & 5.031 & 1.232 \\
\hline City dummy variables & \multicolumn{2}{|c|}{ included } & \multicolumn{2}{|c|}{ not included } & \multicolumn{2}{|c|}{ included } & \multicolumn{2}{|c|}{ not included } \\
\hline Year dummy variables & \multicolumn{2}{|c|}{ included } & \multicolumn{2}{|c|}{ not included } & \multicolumn{2}{|c|}{ included } & \multicolumn{2}{|c|}{ not included } \\
\hline \# of observations & \multicolumn{2}{|c|}{1201} & \multicolumn{2}{|c|}{1201} & \multicolumn{2}{|c|}{1201} & \multicolumn{2}{|c|}{1201} \\
\hline R-squared & \multicolumn{2}{|c|}{0.851} & \multicolumn{2}{|c|}{0.486} & \multicolumn{2}{|c|}{0.928} & \multicolumn{2}{|c|}{0.565} \\
\hline
\end{tabular}

Sources: See Data Appendix. 
Table 5

Non-Infant Mortality Rate Regressions

\begin{tabular}{|c|c|c|c|c|c|c|c|c|}
\hline & \multicolumn{4}{|c|}{ Two Stage Least Squares } & \multicolumn{4}{|c|}{ Ordinary Least Squares } \\
\hline & \multicolumn{2}{|c|}{ Fixed Effects } & \multicolumn{2}{|c|}{ No Fixed Effects } & \multicolumn{2}{|c|}{ Fixed Effects } & \multicolumn{2}{|c|}{ No Fixed Effects } \\
\hline & Coeff. & std. err. & Coeff. & std. err. & Coeff. & std. err. & Coeff. & Std. err. \\
\hline Constant & -15.07 & 9.734 & 13.20 & 8.855 & -12.93 & 6.732 & -4.584 & 4.444 \\
\hline General fertility rate & 0.052 & 0.021 & 0.014 & 0.015 & 0.038 & 0.005 & 0.052 & 0.005 \\
\hline Infant mortality rate & 0.043 & 0.013 & 0.089 & 0.018 & 0.028 & 0.002 & 0.053 & 0.003 \\
\hline Relief spending, per capita & 0.003 & 0.004 & 0.008 & 0.004 & -0.001 & 0.001 & -0.002 & 0.002 \\
\hline Retail sales, per capita & -0.790 & 1.049 & 3.430 & 1.168 & 0.251 & 0.231 & -0.552 & 0.242 \\
\hline Percent black & 0.100 & 0.067 & 0.079 & 0.009 & 0.065 & 0.063 & 0.065 & 0.006 \\
\hline Percent illiterate & 0.041 & 0.070 & 0.045 & 0.066 & 0.093 & 0.067 & 0.137 & 0.027 \\
\hline Percent urban & -0.110 & 0.048 & -0.027 & 0.011 & -0.085 & 0.038 & -0.022 & 0.010 \\
\hline Percent rural, non-farm & -0.113 & 0.059 & -0.027 & 0.014 & -0.084 & 0.048 & -0.036 & 0.012 \\
\hline Percent foreign born & -0.038 & 0.035 & -0.031 & 0.021 & -0.060 & 0.026 & -0.060 & 0.009 \\
\hline \multicolumn{9}{|c|}{ Percentage of total population within: } \\
\hline Ages 10-19 & 0.184 & 0.136 & -0.311 & 0.131 & 0.197 & 0.087 & -0.168 & 0.074 \\
\hline Ages 20-29 & 0.389 & 0.101 & 0.051 & 0.131 & 0.310 & 0.051 & 0.371 & 0.074 \\
\hline Ages $30-34$ & 0.019 & 0.269 & -1.444 & 0.312 & -0.024 & 0.186 & -1.211 & 0.204 \\
\hline Ages 35-44 & 0.606 & 0.130 & 0.316 & 0.211 & 0.529 & 0.095 & 0.673 & 0.134 \\
\hline Ages $45-54$ & 0.400 & 0.202 & -0.270 & 0.233 & 0.256 & 0.095 & -0.113 & 0.114 \\
\hline Ages 55-64 & 0.400 & 0.152 & 0.814 & 0.268 & 0.487 & 0.105 & 1.178 & 0.162 \\
\hline Ages $65-74$ & 0.412 & 0.178 & 0.510 & 0.313 & 0.358 & 0.152 & 0.637 & 0.237 \\
\hline Ages $75+$ & 2.464 & 0.523 & -1.139 & 0.416 & 2.602 & 0.370 & -1.033 & 0.338 \\
\hline City dummy variables & \multicolumn{2}{|c|}{ included } & \multicolumn{2}{|c|}{ not included } & \multicolumn{2}{|c|}{ included } & \multicolumn{2}{|c|}{ not included } \\
\hline Year dummy variables & \multicolumn{2}{|c|}{ included } & \multicolumn{2}{|c|}{ not included } & \multicolumn{2}{|c|}{ included } & \multicolumn{2}{|c|}{ not included } \\
\hline \# of observations & \multicolumn{2}{|c|}{1201} & \multicolumn{2}{|c|}{1201} & \multicolumn{2}{|c|}{1201} & \multicolumn{2}{|c|}{1201} \\
\hline R-squared & \multicolumn{2}{|c|}{0.959} & \multicolumn{2}{|c|}{0.657} & \multicolumn{2}{|c|}{0.962} & \multicolumn{2}{|c|}{0.751} \\
\hline
\end{tabular}

Sources: See Data Appendix. 
Table 6

Amount of Relief Spending Required to Save an Infant's Life

\begin{tabular}{lrrrr}
\hline & \multicolumn{1}{c}{ 2sls FE } & 2sls no FE & OLS FE & OLS no FE \\
\cline { 2 - 4 } & & & & \\
Direct Effect of Relief on Infant Mortality & $\$ 2,477,835$ & $\$ 1,053,697$ & $\$ 7,735,679$ & $\$ 1,554,720$ \\
$\begin{array}{l}\text { Direct and Indirect Effects of Relief on } \\
\quad \text { Infant Mortality }\end{array}$ & $4,305,746$ & 685,228 & $11,458,915$ & $1,034,774$ \\
\hline
\end{tabular}

Notes: Monetary figures reflect year 2000 dollars. Calculations are based on the sample means, assuming a population of 500,000, a ratio of women aged 15-44 to total population of 0.254 , a general fertility rate of 0.06472 births per women aged 15 to 44 (adjusted from the reported per thousand women aged 15 to 44), an infant mortality rate of 0.0538 deaths per live births (adjusted from the reported per thousand live births). The coefficients for the marginal effects are drawn from Tables 3 and 4 for each specification. The coefficient of the infant mortality rate with respect to relief per capita was adjusted by dividing by 1,000 to convert the rate from per 1000 births to per birth. A similar adjustment was made for the coefficient of the general fertility rate with respect to relief per capita. The coefficients of the infant mortality rate with respect to the general fertility rate and the general fertility rate with respect to the infant mortality rate did not need adjustment. The relief costs are insensitive to changes in the population size. They are sensitive to changes in the ratio of women aged 15 to 44 , the general fertility rate, and the infant mortality rate. 


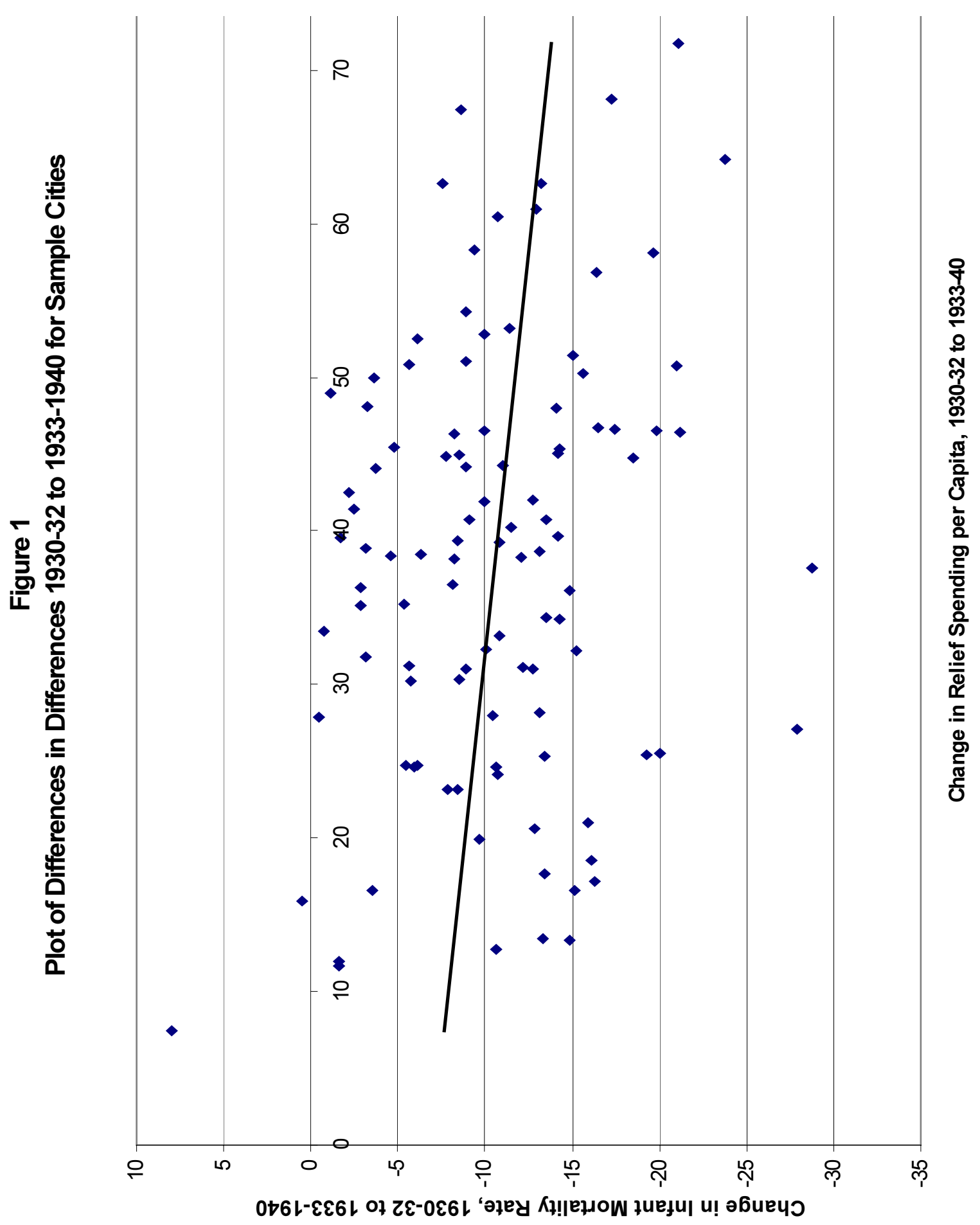




\section{REFERENCES}

Antonovsky, Aaron, and Judith Bernstein, "Social Class and Infant Mortality," Social Science and Medicine 11 (1977), 453-70.

Baird, Enid, Public and Private Aid in 116 Urban Areas, 1929-38, with Supplement for 1939 and 1940, U.S. Federal Security Agency, Social Security Board, Public Assistance Report No. 3 (Washington, DC: Government Printing Office, 1942).

Blank, Rebecca, "Teen Pregnancy: Government Programs Are Not the Cause," Feminist Economics 1 (Summer 1995), 47-58.

Blau, David M., "The Effect of Income on Child Development," Review of Economics and Statistics 81 (May 1999), 261-76.

Clifford, William B., and Yevonne S. Brannon, "Socioeconomic Differentials in Infant Mortality: An Analysis_Over Time," Public Use Data 6 (Jan. 1978), 29-37.

Congressional Quarterly Inc., Guide to U.S. Elections, third edition (Washington, DC: Congressional Quarterly Inc., 1995).

Council of Economic Advisors, Economic Report of the President, January 2001 (Washington, DC: Government Printing Office, 2001).

Currie, Janet, and Nancy Cole, "Welfare and Child Health: The Link between AFDC Participation and Birth Weight," American Economic Review 83 (Sept. 1993), 971-85.

Currie, Janet, and Jonathan Gruber, "Health Insurance Eligibility, Utilization of Medical Care, and Child Health," Quarterly Journal of Economics 11 (May 1996a), 431-66.

"Saving Babies: The Efficacy and Cost of Recent Changes in the Medicaid Eligibility of Pregnant Women," Journal of Political Economy 104 (Dec. 1996b), 1263-96.

"Public Health Insurance and Medical Treatment: The Equalizing Impact of Medicaid Expansions," Journal of Public Economics 82 (Oct. 2001), 63-89.

Currie, Janet, and Duncan Thomas, "Does Head Start Make a Difference?" American Economic Review 85 (June 1995a), 341-64.

"Medical Care for Children: Public Insurance, Private Insurance, and Racial Differences in Utilization," Journal of Human Resources 30 (Winter 1995b), 135-62.

Cutler, David M., and Ellen Meara, "Changes in the Age Distribution of Mortality Over the $20^{\text {th }}$ Century," National Bureau of Economic Research Working Paper 8556, October 2001.

Duncan, Greg J., and Jeanne Brooks-Gunn, eds., Consequences of Growing Up Poor (New York: Russell Sage Foundation, 1997).

Fishback, Price V., Michael R. Haines, and Shawn Kantor, "The Impact of New Deal Programs on Black and White Infant Mortality in the South," Explorations in Economic History 38 (Jan. 2001), 93122.

Fishback, Price V., William C. Horrace, and Shawn Kantor, "Federal Programs in Times of Crisis: The Impact of the New Deal on Local Economies during the Great Depression," National Bureau of Economic Research working paper 8108 (February 2001; revised September 2001).

Fishback, Price V., and Melissa A. Thomasson, "Social Welfare Statistics," in Susan Carter, Richard Sutch, et. al., eds., Millennial Edition of the Historical Statistics of the United States (New York: Cambridge University Press, forthcoming).

Gardner, John, and William Cohen, Demographic Characteristics of the Population of the United States, 1930-1950: County Level, Inter-university Consortium for Political and Social Research, file number 0020, 1992.

Grossman, Michael, and Steven Jacobowitz, "Variations in Infant Mortality Rates Among Counties of the United States: The Roles of Public Policies and Programs," Demography 18 (Nov. 1981), 695713. 
Haines, Michael R., "The Population of the United States, 1790-1920," in Stanley Engerman and Robert Gallman, eds., The Cambridge Economic History of the United States, Volume II (New York: Cambridge University Press, 2000), chapter 4.

"The Relationship between Infant and Child Mortality and Fertility: Some Historical and Contemporary Evidence for the United States," in Mark R. Montgomery and Barney Cohen, eds., From Death to Birth: Mortality Decline and Reproductive Change (Washington, DC: National Academy Press, 1998), 227-53.

"The Urban Mortality Transition in the United States, 1800 to 1940," Annales de demographie historique, forthcoming.

Haveman, Robert H., and Barbara S. Wolfe, Succeeding Generations: On the Effects of Investments in Children (New York: Russell Sage Foundation, 1994).

Horrace, William C., and Ronald L. Oaxaca, "New Wine in Old Bottles: A Sequential Estimation Technique for the LPM," University of Arizona working paper, 2001.

Inter-University Consortium for Political and Social Research, Historical, Demographic, Economic, and Social Data: The United States, 1790-1970, file number 0003. The version has additions and corrections by Michael Haines, Department of Economics, Colgate University, Hamilton, NY. , United States Historical Election Returns, 1824-1968, file number 0001.

Joyce, Theodore, "Impact of Augmented Prenatal Care on Birth Outcomes of Medicaid Recipients in New York City," Journal of Health Economics 18 (Jan. 1999), 31-67.

Moffitt, Robert A., and Michele Ver Ploeg, Evaluating Welfare Reform in an Era of Transition (Washington, DC: National Academy Press, 2001)

Moore, Michael J., and W. Kip Viscusi, Compensation Mechanisms for Job Risk: Wages, Workers' Compensation and Product Liability (Princeton, NJ: Princeton University Press, 1990).

New York Secretary of State, Manual, various years, 1925-1940.

Paxson, Christina, and Jane Waldfogel, "Parental Resources and Child Abuse and Neglect," American Economic Review, Papers and Proceedings 89 (May 1999), 239-44.

Skocpol, Theda, Protecting Soldiers and Mothers: The Political Origins of Social Policy in the United States (Cambridge, MA: Belknap Press 1992).

Stevens, Robert B., Statutory History of the United States: Income Security (New York: Chelsea House Publishers, 1970).

Thompson, Laura, Laws Relating to 'Mothers' Pensions' in the United States, Canada, Denmark, and New Zealand, U. S. Department of Labor, Children's Bureau Publication No. 63, Legal Series No. 4 (Washington DC: Government Printing Office, 1919).

U.S. Bureau of the Census, Birth Stillbirth, and Infant Mortality Statistics for the Birth Registration Area of the United States, 1930, Sixteenth Annual Report (Washington, DC: Government Printing Office, 1934a).

U.S. Bureau of the Census, Birth Stillbirth, and Infant Mortality Statistics for the Birth Registration Area of the United States, 1931, Seventeenth Annual Report (Washington, DC: Government Printing Office, 1934b).

U.S. Bureau of the Census, Birth Stillbirth, and Infant Mortality Statistics for the Birth Registration Area of the United States, 1932, Eighteenth Annual Report (Washington, DC: Government Printing Office, 1934c).

U.S. Bureau of the Census, Birth Stillbirth, and Infant Mortality Statistics for the Continental United States, The Territory of Hawaii, and the Virgin Islands, 1933, Nineteenth Annual Report (Washington, DC: Government Printing Office, 1936a).

U.S. Bureau of the Census, Birth Stillbirth, and Infant Mortality Statistics for the Continental United States, The Territory of Hawaii, and the Virgin Islands, 1934, Twentieth Annual Report (Washington, DC: Government Printing Office, 1936b).

U.S. Bureau of the Census, Birth Stillbirth, and Infant Mortality Statistics for the Continental United States, The Territory of Hawaii, and the Virgin Islands, 1935, Twenty-First Annual Report 
(Washington, DC: Government Printing Office, 1937).

U.S. Bureau of the Census, Birth Stillbirth, and Infant Mortality Statistics for the Continental United States, The Territory of Hawaii, and the Virgin Islands, 1936, Twenty-Second Annual Report (Washington, DC: Government Printing Office, 1938).

U.S. Bureau of the Census, Birth Stillbirth, and Infant Mortality Statistics for the Continental United States, The Territory of Hawaii, and the Virgin Islands, 1937, Twenty-Third Annual Report (Washington, DC: Government Printing Office, 1939).

U.S. Bureau of the Census, Birth Stillbirth, and Infant Mortality Statistics for the Continental United States, The Territory of Hawaii, and the Virgin Islands, 1938, Twenty-Fourth Annual Report (Washington, DC: Government Printing Office, 1940).

U.S. Bureau of the Census, Birth Stillbirth, and Infant Mortality Statistics for the Continental United States, The Territory of Hawaii, and the Virgin Islands, 1939, Twenty-Fifth Annual Report (Washington, DC: Government Printing Office, 1941).

U.S. Bureau of the Census, Birth Stillbirth, and Infant Mortality Statistics for the Continental United States, The Territory of Hawaii, and the Virgin Islands, 1940, Twenty-Sixth Annual Report (Washington, DC: Government Printing Office, 1942).

U.S. Bureau of Census, Historical Statistics of the United States: Colonial Times to 1970 (Washington, DC: Government Printing Office , 1975).

U. S. Bureau of Economic Analysis, State Personal Income: 1929-1987 (Washington, DC: Government Printing Office, 1989).

U.S. Bureau of Labor Statistics, "Public Provision for Pensions for the Blind in 1934," Monthly Labor Review 41 (Sept. 1935), 584-601.

U.S. Committee on Economic Security, Social Security in America: The Factual Background of the Social Security Act as Summarized from Staff Reports to the Committee on Economic Security (Washington, DC: Government Printing Office, 1937).

U.S. Congress, Official Congressional Directory, $73^{\text {rd }}$ Congress $1^{\text {st }}$ session through $76^{\text {th }}$ Congress (Washington, DC: Government Printing Office, various years).

U.S. Department of Commerce, Bureau of Foreign and Domestic Commerce, Consumer Market Data Handbook, 1936 (Washington, DC: Government Printing Office, 1936)

U.S. Department of Commerce, Bureau of Foreign and Domestic Commerce, Consumer Market Data Handbook, 1939. (Washington, DC: Government Printing Office, 1939).

U.S. National Resources Planning Board, Security, Work, and Relief Policies (Washington, DC: Government Printing Office, 1942).

Waldmann, Robert J., "Income Distribution and Infant Mortality," Quarterly Journal of Economics 107 (Nov. 1992), 1284-302.

Wallis, John Joseph. "The Political Economy of New Deal Spending Revisited, Again: With and Without Nevada," Explorations in Economic History 35 (April 1998), 140-70.

White, Halbert, "A Heteroskedasticity-Consistent Covariance Matrix Estimator and a Direct Test for Heteroskedasticity," Econometrica 48 (May 1980), 817-38.

Winslow, Emma A., Trends in Different Types of Public and Private Relief in Urban Areas, 1929-35, U.S. Department of Labor, Children's Bureau Publication No. 237 (Washington, DC: Government Printing Office, 1937). 